\title{
Recent Studies on Byzantine Sigillography in Turkey
}

\section{Esra Guzel Erdogan (Dr.)}

\author{
Assistant Professor \\ Marmara University \\ School Of Social Sciences \\ Istanbul (Turkey)
}

\section{Doi:10.5901/mjss.2013.v4n10p13}

\section{Abstract}

This paper will focus on the recent studies on Byzantine sigillography which are taken place in Turkey. Although, Turkey should be considered as one of the heirs of Byzantine Empire, the studies which focus on byzantine lead seals are extremely rare. First part of this paper will summarize on the history of sigillography in Turkey which gained a new momentum for the last five years. Studies on the subject became very popular among young scholars mainly after the lecture that was given by French scholar Jean-Claude Cheynet from Sorbonne University. Cheynet's lecture on Byzantine sigillography was presented in 2008 and the international project called SigiDoc started after it. This project aims to create a database which can be accessible by every scholars. Within this project the first publication is on Istanbul Archeological Museum's lead seal collection was published in 2012. During the preparative and editorial unfortunately we came across the poor conservation conditions of this important collection. The last part of the present paper will give brief information on the latest studies through the world on sigillography which are computer-based.

Keywords: seals, Byzantine, Turkey.

At first, it is possible to give some brief information of the seals and their characteristics during the reign of Byzantine Empire. Most of them were made of lead. Also, as far as one may know there were various samples of wax seals but since the material was quite fragile we do not have any which are suitable to examine. Another material of the seals was silver, but they are also rare since costs of the production of silver seals were so high. According to Oikonomides, traditional materials for seal were wax and clay, but under the Romans lead seals began to be used (Oikonomides, 1985, p. 3). Majority of the lead seals were in use from $6^{\text {th }}$ century till the end of the Byzantine Empire in $15^{\text {th }}$ century. Roman Empire used seals for commercial purposes, Byzantines used them extensively for various reasons, such as military, civil, religious, imperial, administrative and commercial works (Cheynet \& Caseau, 2009, p. 134). On the other hand, the main purpose of sealing was never changed, it was stood for signature and it was the guarantee of the document in question wasn't opened by unauthorized people.

In 2011, The International Congress on Byzantine Studies held in Sofia, there was a round table meeting on Byzantine sigillography. Ivan Jordanov, who is one of the leading scholar in Byzantine Sigillography mentioned that the earliest studies on Byzantine sigillography in Bulgaria goes back to the beginning of the $20^{\text {th }}$ century (Jordanov, $2011, p$. 101)

Unfortunately, studies on Byzantine sigillography quite unpopular in Turkey, even though most of the seals originated from those lands. Moreover, there is this one book on the subject in Turkish, which was written by Vera Bulgurlu in 2007. Bulgurlu's book included only one the part of lead seal collection of the Istanbul Archeological Museum (Bulgurlu, 2007). This book was the re-print of the Bulgurlu's PhD dissertation. In addition, the articles that were about the Byzantine sigillography were also a few in numbers, among them we should mention one more particular name. Turan Gökyıldırım, who had published several articles on Byzantine lead seals is an archeologist and also the former head of the seal section. On the other hand, it is a pleasing improvement that we can talk about a growing interest on Byzantine seals among young scholars.

In 2008, Jean Claude Cheynet, who is one of the most important sigillographer and a professor in Sorbonne University had a conference in Istanbul. This conference can be considered a beginning of a new epoch in Byzantine sigillography studies in Turkey. Cheynet not only talked about lead seals in general but also he presented a new project called SigiDoc. SigiDoc project can be described as to create a worldwide database that inclueds all the seals and keeps them ready for examinations by the scholars. Under the light of this brief introduction one should also explain the details of SigiDoc project. First of all, it is one part of EpiDoc project which can be defined as entering epigraphic documents 
into a shared database. It aims to create a common alphabet and common ligature in order to serve to the every sigillographers. It is possible to claim that this database is created partially by Dumbarton Oaks Research Center. Dumbarton Oaks prepared a database of its entire collection and composed an alphabet which was called athena ruby. Along with this alphabet, this study offers a list of bibliography, ligatures and a dictionary. Moreover, it aims to cover 17.000 seals when it is completed.

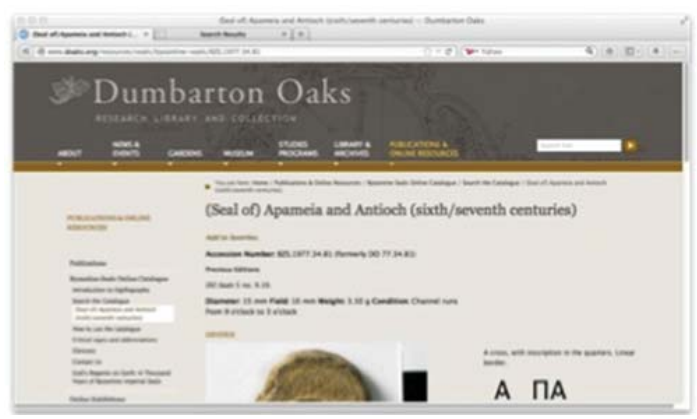

Photo 1. Dumbarton Oaks Research Center (www.doaks.org)

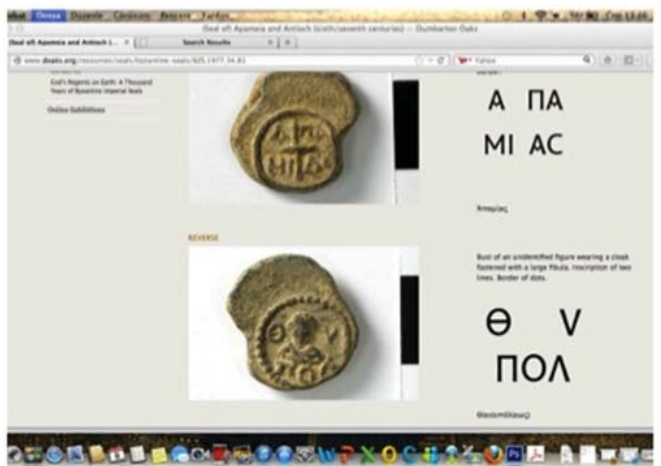

Photo 2. Dumbarton Oaks Research Center (www.doaks.org)

In addition, there is also another study under the Prosopography in Byzantine World. This project is also covers various museum and private lead seal collections, including Istanbul, Tarsus and Selçuk museums' collections.

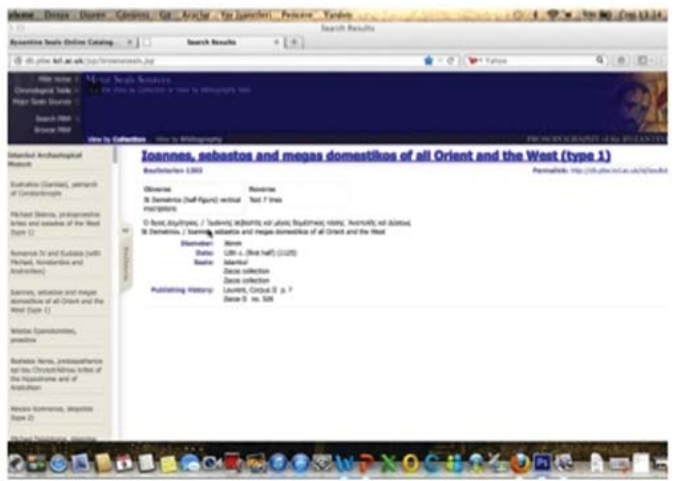

Photo 3. Prosopography of Byzantine World (http://db.pbw.kcl.ac.uk/jsp/index.jsp) 
As the first step of the SigiDoc project, a new book was published by Cheynet, Gökyıldırım and Bulgurlu under the editorialship of E.G. Erdoğan. This book includes almost the entire lead seal collection of the Istanbul Archeological Museum (Cheynet, Gökyıldırım \& Bulgurlu, 2012). During the long process of composing this book, we had a chance to observe the conservation circumstances of the Istanbul Archaeological Museum. Most of the specimens are kept in the basic lockers which were made up oak most probably in 1950's. But the oak is a material that may have chemical reactions with the lead and caused corrosion. This paved the way for disappearance of the letters and icons surprisingly in a very short time.

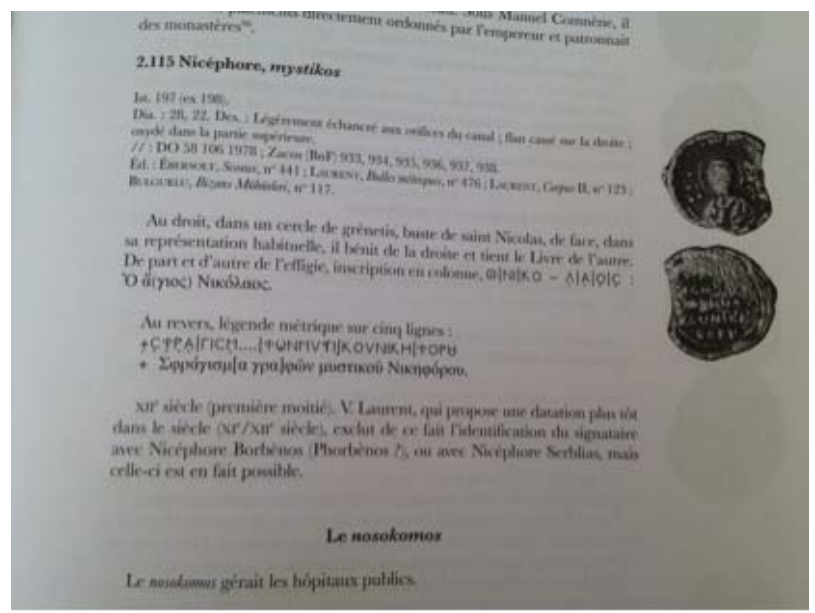

Photo 4. Cheynet, Gökyıldırım\&Bulgurlu, 2012

Consequently, museum lead seal collections in Turkey acquisited mostly through confiscations or donations not by excavations. During the research process of the issued study, personally witnessed the increasing interest of the lead seal in Turkey. It is possible to mention some web pages which displays various samples from museums tagged with the prices. It is really hard to distinguish that whether they serve for the scholars or for the smugglers.

\section{References}

Bulgurlu, V., 2007, Bizans Kurşun Mühürleri, İstanbul.

Cheynet, J.Cl. \& Caseau B., , 2012, Sealing Practices in the Byzantine Administration, Developments in Administration and Magic from Prehistory to the Islamic Period, Proceedings of an International Workshop at the Netherlands- Flemish Ins. In Cairo on December 2-3, 2009, Leuven-Paris-Walpole MA, 133-148.

Cheynet, J.Cl, Gökyıldırım, T., V. Bulgurlu, 2012, Les sceaux byzantins du Musée archeologique d'Istanbul, (ed. E.G. Erdoğan), Istanbul.

Jordanov, I., 2011, The Byzantine World and the Sigillography, Proceedings of the 22th International Congress of Byzantine Studies, Sofia, 22-27 August, 2011, 101-102. 